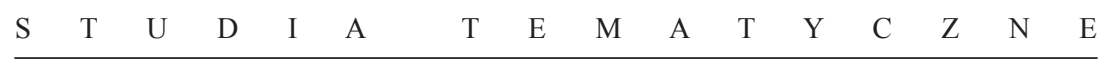

STUDIA Z PRAWA WYZNANIOWEGO

Tom $21-2018$

DOI: https://doi.org/10.31743/spw.196

TADEUSZ STANISŁAWSKI*

\title{
FORMY ZATRUDNIENIA DUCHOWNEGO W INSTYTUCJACH KOŚCIELNYCH PO II WOJNIE ŚWIATOWEJ
}

\section{Streszczenie}

Celem niniejszego artykułu jest wskazanie istniejących możliwości zatrudniania osób duchownych w ramach organizacji kościelnej, tzn. przede wszystkim przez tzw. kościelnych pracodawców. W pierwszej części opracowania przedstawiona została sytuacja w tym zakresie w czasie od zakończenia II wojny światowej do przełomu roku 1989. W tym okresie ścierały się stanowiska władz państwowych i kościelnych, a władze państwowe traktowały instrumentalnie kwestie zatrudnienia duchownych, podobnie jak ich ubezpieczenie społeczne czy też opodatkowanie. W przedstawieniu tematyki sięgnięto do aktów prawnych oraz źródeł archiwalnych ilustrujących ówczesny sposób stosowania prawa. Po roku 1989 kontekst społeczno-ekonomiczny uległ zasadniczym zmianom. Jednostki kościelne mogą zatrudniać duchownych bez przeszkód na podstawie stosunku pracy. Wybór sposobu zatrudnienia pozostaje $\mathrm{w}$ kwestii samych duchownych oraz zatrudniających ich podmiotów kościelnych. Przedstawienie tych możliwości oraz zarysowanie płynących z tej sytuacji korzyści oraz zagrożeń stanowi cel drugiej części niniejszego opracowania.

Słowa kluczowe: zatrudnianie duchownych: formy zatrudnienia; wynagrodzenie; praca; duchowny; pracodawca kościelny; związek wyznaniowy

\section{$* * * * *$}

Kwestie wewnętrznej struktury kościołów i innych związków wyznaniowych, obsadzania stanowisk i urzędów, kształcenia i doboru kadr - sta-

* Ks. dr hab., prof. UZ, Katedra Prawa Administracyjnego i Finansowego, Wydział Prawa i Administracji, Uniwersytet Zielonogórski, pl. Słowiański 9, 65-069 Zielona Góra, e-mail: tstanis@kul.pl. ORCiD 0000-0002-0843-0633. 
nowią aktualnie jeden z głównych przejawów autonomii i wzajemnej niezależności państwa i instytucji wyznaniowych ${ }^{1}$. Nie oznacza to jednak, iż w historii wzajemnych stosunków problem ten zawsze pozostawiał bezdyskusyjny i jednoznaczny - przeciwnie, niemal zawsze stanowił przedmiot sporów i swoistej konkurencji kompetencji w tym zakresie. Poza obszarem niniejszego opracowania pozostają jednak zupełnie historyczne już obecnie spory między władzą świecką a duchowną o przywileje prezentowania kandydatów na wyższe stanowiska kościelne (co najmniej biskupów) czy spory o powierzanie beneficjów związanych z pełnieniem odpowiednich urzędów kościelnych. Przerwa w ciągłości polskiej państwowości spowodowana rozbiorami nie pozostała bez znaczenia również dla przedmiotu tego artykułu. Na ten bowiem okres przypadł proces sekularyzacji dóbr kościelnych i ukształtowania się całego kompleksu świadczeń zamiennych, różnych dla różnych państw i tradycji. Polska siłą rzeczy w tym nie uczestniczyła, a zadanie opracowania wspólnego modelu stanęło przed Państwem i Kościołem w II Rzeczypospolitej. Regulacje Konkordatu z 1925 r. w tym zakresie wprowadzały kilka zasad ${ }^{2}$. Po pierwsze wprowadzały wynagrodzenie ze środków publicznych (budżetu) związane z pełnieniem urzędów kościelnych, po drugie zapewniały opodatkowanie dochodów duchownych na zasadach równouprawnienia z innymi podatnikami, tzn. zasadniczo podatkiem dochodowym ${ }^{3}$. Takie rozwiązanie upodobniało wynagrodzenia duchownych do wynagrodzeń osiąganych ze stosunku pracy. Poza zainteresowaniem tych przepisów pozostały ubezpieczenia społeczne i zdrowotne. W związku z dożywotnim wówczas (do czasu Kodeksu Prawa Kanonicznego z 1983 r.) pełnieniem urzędów kościelnych (tzn. brakiem wieku emerytalnego) duchowni nie byli zasadniczo zainteresowani udziałem $\mathrm{w}$ - skądinąd będącym w początkowych fazach rozwoju - systemie ubezpieczeniowym.

Z takim dziedzictwem Kościół Katolicki, a jednocześnie inne kościoły i związki wyznaniowe, wszedł w rzeczywistość po II wojnie światowej zupełnie odbiegającą od dotychczasowych realiów i doświadczeń.

Garlicki 2003, 17.

2 Konkordat pomiędzy Stolicą Apostolską a Rzecząpospolitą Polską, podpisany w Rzymie dnia 10 lutego 1925 r., Dz. U. z 1925 r. Nr. 72, poz. 501 i 502.

Art. XV Konkordatu z 1925 r. 


\section{OKRES POWOJENNY DO 1989 R.}

Po zakończeniu II wojny światowej, a przede wszystkim po zmianie systemu polityczno-ekonomicznego w Polsce, spory między władzami partyjno-państwowymi a kościołami i innymi związkami wyznaniowymi toczyły się na wielu obszarach. Jednym z ważniejszych była kwestia opodatkowania i ubezpieczeń społecznych.

Władze podtrzymały przedwojenną zasadę opodatkowania dochodów duchownych podatkiem dochodowym. Z jednym, fundamentalnym, zastrzeżeniem - to już nie był ten sam, ani taki sam podatek. Był to natomiast jeden z instrumentów ekonomicznej likwidacji pozostałości systemu kapitalistycznego, do której to grupy zostali zaliczeni podatnicy właśnie podatku dochodowego. Inne grupy zawodowe były podatnikami dużo korzystniejszego podatku od wynagrodzeń, a z czasem kolejne grupy były z opodatkowania całkowicie zwalniane.

Podobne podejście - powoływanie się na obowiązujące w II Rzeczypospolitej zasady - władze prezentowały w kwestii ubezpieczenia społecznego. Również w tej kwestii duchowni do końca trwania PRL pozostawali poza systemem powszechnego ubezpieczenia społecznego z racji pozostawania w stanie duchownym ${ }^{4}$. Nieliczne wyjątki stanowili duchowni pozostający w stosunku pracy (seminarium, kuria, KUL), albo przychylnie traktowani przez władze z racji różnych form współpracy.

Wyjściem z tej trudnej sytuacji wydawało się podjęcie starań o zakwalifikowanie posługi duchownych pracujących w duszpasterstwie jako zatrudnienia. Mogło to w konsekwencji oznaczać objęcie tych dochodów korzystniejszym podatkiem od wynagrodzeń, zwolnieniem od uciążliwej księgowości podatku dochodowego (księga podatkowa nr 11) oraz włączenie duchownych do systemu ubezpieczeń społecznych.

Dekret o podatku od wynagrodzeń z 1945 roku, podając definicję wynagrodzenia, określił je jako „wszelkiego rodzaju świadczenie w pieniądzach lub naturze, otrzymywane przez pracownika z tytułu pełnionej przez niego pracy zarówno w czasie trwania stosunku służbowego lub stosunku umownego o pracę, jak i po jego ustaniu"s. Jednak już w 1947 roku rozporządzenie Ministra Skarbu sprecyzowało, iż:

$4 \quad$ Stanisz 2005, 271-295. 
„Nie uważa się za wynagrodzenie:

a) sum wypłacanych z funduszów Państwa, samorządu lub z innych funduszów publicznych duchowieństwu prawnie uznanych wyznań religijnych na zasadach przepisów regulujących stosunek Państwa do tych wyznań.

b) przychodu duchownych z opłat stuły, z opłat za odprawianie mszy itp. oraz z innych darów, jakie duchowni otrzymują ze względu na swój urząd"6.

Taka interpretacja pojęcia wynagrodzenia wpływała na istotne zawężenie zakresu podmiotowego tego podatku w odniesieniu do duchownych. Utrudniała również znacznie, a praktycznie uniemożliwiała, stosowanie tego rodzaju opodatkowania w przypadku duchownych pracujących w duszpasterstwie.

Już w momencie pojawienia się trudności wynikających z opodatkowania podatkiem gruntowym ziem beneficjalnych, a następnie podejmowanych prób podziału tych nieruchomości i wyodrębnienia poszczególnych podmiotów podatkowych uwidoczniły się projekty zmian systemu utrzymania osób duchownych. „Nowe zasady gospodarki ziemią, jak i obecna polityka podatkowa państwa zmuszają do ewentualnej zmiany systemu wynagradzania księży tam, gdzie Biskupi Ordynariusze uznają to za stosowne. Zamiast z ziemi otrzymałby ksiądz proboszcz ugotowanie z kasy kościelnej"7.

Komisja Finansowa Episkopatu Polski w dniu 22 sierpnia 1949 roku $^{8}$ postulowała wprowadzenie, jako wynagrodzenia wszystkich osób duchownych, pensji wypłacanych z kas poszczególnych kościelnych osób prawnych - będących w tym wypadku pracodawcami. W ten sposób dokonana zostałaby zasadnicza zmiana systemu wynagradzania duchownych pracujących w duszpasterstwie.

5 Art. 2 ust. 1 dekretu z dnia 18 sierpnia 1945 r. o podatku od wynagrodzeń, Dz. U. z 1945 r. Nr 32, poz. 220 z późn. zm.

6 Rozporządzenie Ministra Skarbu z dnia 21 czerwca 1947 r. w sprawie wykonania dekretu z dnia 18 sierpnia 1945 r. o podatku od wynagrodzeń, do art. 2 ust. 1 , § 4 ust. 1 , Dz. U. z 1947 r. Nr 54, poz. 291.

7 Dotyczy ziem beneficjalnych, opr. kościelne, 1948 r., Archiwum Sekretariatu Konferencji Episkopatu Polski (dalej: ASEP), sygn. 6202, s. 10.

Protokół z posiedzenia Komisji Finansowej Episkopatu Polski odbytej w Krakowie w dniu 22 sierpnia 1949 r., ASEP, sygn. 62001, s. 33. 
Miałoby się to odbywać poprzez przekazywanie do kasy odpowiedniej osoby prawnej wszelkich wpływów osiąganych przez duchownego w związku z zaspokajaniem potrzeb religijnych (nie wyłączając stypendiów mszalnych), a następnie ustalenie i wypłacanie wynagrodzenia. Tym samym nastąpiłoby wyłączenie tych sum z podatku dochodowego, a objęcie ich podatkiem od wynagrodzeń.

Wysokość pensji uzależniano w tym projekcie od wysokości dochodów poszczególnych osób prawnych. Miała ona podlegać zatwierdzeniu przez właściwą Kurię Biskupią. Nie pretendowało to zatem do stworzenia systemu ujednoliconego wynagradzania duchownych w szerszej skali (diecezji czy nawet kraju), jeśli chodzi o wysokość pobieranych świadczeń, postulowano jedynie ustalenie jednolitej dla wszystkich diecezji formy ksiąg kasowych. Takie rozwiązanie pociągało jednak za sobą szereg trudności, między innymi konieczność udostępnienia władzom finansowym w celu kontroli całej księgowości parafii.

Jako argument za takim rozwiązaniem przytoczono, oprócz niższej skali opodatkowania, uchylenie również obowiązku prowadzenia księgi podatkowej nr 11 (powołując się na oświadczenie Dyrektora Departamentu w Ministerstwie Skarbu z obrad mieszanej komisji ekspertów z 19 sierpnia tegoż roku). Wiązało się to także jednocześnie z ominięciem obowiązku księgowania wśród osobistych dochodów duchownych, także sum przechodnich, a więc przychodów kościelnych osób prawnych.

Dostępna dokumentacja pozwala stwierdzić, że podjęte zostały próby takiego właśnie uregulowania kwestii wynagradzania pracy duchownych w niektórych diecezjach ${ }^{9}$. Sekretariat Episkopatu przewidywał jednak wkrótce powstanie na tym tle trudności ${ }^{10}$.

9 „Gros duchowieństwa naszej Diecezji zrzekło się dochodów z ziemi, którą przepisała Kuria Biskupia na kult religijny, dochodów z iura stolae i intencji mszalnych, które wpływają do kasy kościelnej i przeszła na pensję miesięczną, od której na mocy miesięcznej deklaracji płacą Księża podatek od wynagrodzeń. Tego rodzaju wynagrodzenie zwalnia od prowadzenia księgi podatkowej, wobec wyraźnego przepisu dekretu i zgody Ministra Skarbu - Dyr. Kałakowski. - Zapytujemy, czy ta praktyka może nastręczać trudności i zmusić Księży do prowadzenia księgi podatkowej?”. Pismo Kurii Biskupiej Chełmińskiej z dnia 3 stycznia 1950 r. do bp. Choromańskiego, nr 26/50/IV, ASEP, sygn. 62001, s. 49.

10 „Spieszę z wyjaśnieniem, że kto otrzymuje wynagrodzenie i płaci od niego podatek, nie jest obowiązany do prowadzenia książki Nr 11. Inna sprawa, czy w przyszłości władze 
Jeszcze jednak w 1951 r. istniały opracowania kościelne stojące na stanowisku, że możliwe jest podzielenie dochodów duchowieństwa pracującego w duszpasterstwie parafialnym. Postulowano wyodrębnienie przychodów otrzymywanych w związku z pełnieniem funkcji duszpasterskich (iura stolae, stypendia mszalne itp.) i opodatkowanie ich podatkiem dochodowym, a następnie wypłacanie z kasy parafialnej wynagrodzenia duchownym pełniącym funkcje administracyjno-urzędnicze w parafiach (zarząd majątku kościelnego, administracja budynków i cmentarzy, prowadzenie księgowości itp.) i opodatkowanie tej części podatkiem od wynagrodzeń. Jednocześnie sumy wynagrodzeń traktowano jako koszty funkcjonowania parafii, które nie powodowały utraty zwolnienia z opodatkowania podatkiem dochodowym ${ }^{11}$.

Jak już zostało to odnotowane, duchowni zatrudnieni na podstawie umowy o pracę lub stosunku służbowego stanowili znikomą mniejszość, w dokumentach pojawia się liczba 500 osób $^{12}$. Uznawano za takich biskupów diecezjalnych i pomocniczych, pracowników kurii i domów prowincjalnych, profesorów uczelni kościelnych, prefektów szkół, kapelanów różnego rodzaju i innych. O przynależności do tej grupy decydowało otrzymywanie wynagrodzenia na podstawie listy płac lub uzyskiwanie dochodów płynących z pracy najemnej ${ }^{13}$.

Kolejną próbą, podjętą lokalnie, było zatrudnienie wikariusza parafii w charakterze kościelnego i wypłacenie mu z tego tytułu wynagrodzenia. Sumę tego wynagrodzenia z kolei zakwalifikowano jako koszt funkcjonowania parafii i odliczono od podstawy opodatkowania podatkiem dochodowym. W odnalezionej korespondencji prowadzonej w tej sprawie między Urzędem do Spraw Wyznań a Ministerstwem Finansów, ministerstwo to nie widziało zasadniczych trudności w takim właśnie za-

skarbowe będą honorowały pensje duchowieństwa”. Pismo Sekretarza Episkopatu Nr 50 z dnia 7 stycznia 1950 r. do Kurii Chełmińskiej, ASEP, sygn. 62001, s. 50.

11 Por. Czy Kościól Katolicki jako osoba prawna podlega podatkowi?, opr. kościelne, po 28 lutego 1951 r., ASEP, sygn. 620110, s. 34-39.

12 Notatka w sprawie reformy opodatkowania osób duchownych, 13 czerwca 1966 r., Archiwum Akt Nowych (dalej: AAN), Urząd do Spraw Wyznań (dalej: UdSW), sygn. 125/507, s. 75 .

13 Okólnik Zarządu podatków i opłat Ministerstwa Finansów w sprawie zasad opodatkowania duchowieństwa, 26 stycznia 1957 r., tekst w: Raina 1994, 585-586. 
kwalifikowaniu sum wypłacanych wikariuszom za pracę świadczoną na rzecz parafii. Dopuszczono także możliwość zawierania innych umów, również bez formy pisemnej, skutkujących powstaniem stosunku pracy. Powoływano się zarazem na ogólne przepisy prawa cywilnego. Zgodnie jednak z zasadami przyznającymi wyjątkowe kompetencje administracji wyznaniowej, kolejny raz okazało się, że to właśnie Urząd do Spraw Wyznań podejmował ostateczne i wiążące decyzje w sprawie interpretacji przepisów prawa podatkowego odnośnie do podatników kościelnych. Nie uważał on nawet za stosowne uzasadniać swoich rozstrzygnięć odpowiednimi przepisami prawa, których ewentualną korektę sugerowało Ministerstwo Finansów ${ }^{14}$.

14 „Parafia (w Jastarni - przyp. autora) wypłaciła wikariuszowi w roku 1959 kwotę 7200 zł. z tytułu pełnienia przez niego funkcji kościelnego. W myśl wydanych przez Ministerstwo Finansów zarządzeń co do opodatkowania kościelnych osób prawnych wynagrodzenia służby kościelnej zaliczane są do kosztów funkcjonowania parafii. Z punktu widzenia ogólnego prawa cywilnego brak jest podstaw do twierdzenia, że osoba duchowna nie może pozostawać w stosunku pracy z parafią, w której spełnia funkcje duszpasterskie i wykonywać np. czynności księgowego parafii za wynagrodzeniem. Dla stwierdzenia stosunku pracy nie koniecznie wymagana jest umowa na piśmie. Z tych też względów brak byłoby podstaw prawnych do nieuznania jako kosztów funkcjonowania wynagrodzeń wypłaconych wikariuszowi za pełnienie dodatkowych czynności na rzecz parafii. Niemniej jednak istnieje pewne niebezpieczeństwo bezkrytycznego uznawania sum wynagrodzeń wypłacanych przez parafie osobom duchownym, które pełnią zasadniczo funkcje duszpasterskie i administracyjne w parafii. Umożliwiałoby to bowiem parafiom wypłacanie pewnych sum na utrzymanie osób duchownych pod pozorem rzekomego wykonywania przez nich jakichś zleconych czynności pomocniczych. Gdyby Urząd do Spraw Wyznań stanął na stanowisku, że w żadnym wypadku pomiędzy osobą duchowną np. pomiędzy proboszczem lub wikariuszem a parafią nie może istnieć stosunek pracy i wobec tego nie mogą być wypłacane im wynagrodzenia za wykonywanie zleconych czynności należałoby, zdaniem Ministerstwa Finansów, przed wydaniem organom finansowym odpowiednich wytycznych w tej sprawie spowodować zmianę odpowiednich przepisów prawa pracy, co należałoby do kompetencji Komitetu Pracy i Płacy. (...)". Pismo Dyrektora Departamentu Podatków i Opłat Ministerstwa Finansów nr PO 12321/7/61 z dnia 23 października 1961 r. do Urzędu do Spraw Wyznań w Warszawie, AAN, UdSW, sygn. 64/34, s. niepag.

„Zdaniem Urzędu kapłan nie może i nie wykonuje funkcji kościelnego i zakrystiana, toteż wydatek o którym pisze parafia jest próbą obejścia przepisów podatkowych. W rzeczywistości jest to zamaskowanie wydatku na utrzymanie duchownego, które faktycznie powoduje pozbawienie przywileju zwolnienia parafii od podatku. (...)" Odpowiedź Urzędu do Spraw Wyznań nr II. 6c/19/62 z dnia 7 marca 1962 r., AAN, UdSW, sygn. 64/34, s. niepag. 
Można zatem stwierdzić istnienie uregulowań zawężających zakres podmiotowy i przedmiotowy w podatku od wynagrodzeń w odniesieniu do osób duchownych. Sprawiało to, iż coraz większa część ich dochodów była opodatkowana podatkiem dochodowym, charakteryzującym się przede wszystkim wyższymi stawkami procentowymi. Prowadzono próby całkowitego wyeliminowania podatku od wynagrodzeń przynajmniej w odniesieniu do duchownych zatrudnionych w instytucjach kościelnych. Urząd do Spraw Wyznań przewidywał wręcz „wywołanie” uchwały Sądu Najwyższego w celu stwierdzenia braku istnienia w tych wypadkach stosunku pracy ${ }^{15}$.

Ustawa o podatku od wynagrodzen ${ }^{16}$ została uchylona dopiero ustawą o podatku dochodowym od osób fizycznych ${ }^{17}$, która obejmuje dotychczasowe opodatkowanie wynagrodzeń. Jednak już od roku 1956, kiedy to wprowadzono ryczałtową formę opodatkowania podatkiem dochodowym przychodów osiąganych przez duchownych z racji pełnienia przez nich posług duszpasterskich, zagadnienie to straciło na znaczeniu. Zrezygnowano z uciążliwej księgowości, stawki podatku ryczałtowego okazały się do zaakceptowania, jeśli chodzi o ich wysokość. W nadchodzących latach aktywność aparatu skarbowego i wyznaniowego w tym zakresie skierowała się raczej w stronę kościelnych osób prawnych, a nie duchownych.

Podsumowując ten okres można stwierdzić, iż władze kościelne poszukiwały rozwiązania formalnego najlepiej spełniającego wymagania konkretnej epoki. Proponowane wyjścia z opresyjnej sytuacji koncentrowały się na próbach: uproszczenia księgowości, obniżenia stawek podatkowych, uniknięcia sankcji podatkowych, udziału w systemie ubezpieczeń społecznych. Nie powodowały one zmian w prawie wewnętrznym Kościoła, systemie przekazywanych ofiar i innych świadczeń, a tylko były zabiegami formalnymi, poszukującymi w przepisach prawa państwowego przestrzeni na korzystniejsze potraktowanie istniejących rozwiązań i form pełnienia posługi duszpasterskiej. Nie miały też powodować żadnych modyfikacji

15 Notatka w sprawie reformy opodatkowania osób duchownych, 13 czerwca 1966 r., AAN, UdSW, sygn. 125/507, s. 76.

16 Ustawa z dnia 4 lutego 1949 r. o podatku od wynagrodzeń, weszła w życie 16 lutego 1949 r., z mocą od 1 stycznia 1949 r. (sic!), Dz. U. z 1949 r. Nr 7, poz. 41.

17 Ustawa z dnia 26 lipca $1991 \mathrm{r}$. o podatku dochodowym od osób fizycznych, tekst jedn. Dz. U. z 2018 r., poz. 1509 z późn. zm. (dalej: u.p.d.f.). 
w zakresie powierzania i wypełniania zadań urzędów kościelnych, charakteru pracy duchownego, jej zakresu, czasu, miejsca itp.

\section{SYTUACJA WSPÓŁCZESNA}

Po zmianie systemu społeczno-politycznego zapoczątkowanej w roku 1989 wiele z dotychczasowych problemów znalazło swoje inne, korzystniejsze rozwiązanie albo straciło na aktualności. Duchowni zostali włączeni do systemu ubezpieczeń społecznych począwszy od ustawy z 1989 r. $^{18}$, a kończąc na obecnie obowiązujących rozwiązaniach w tym zakresie od roku $1999^{19}$. Pracując w duszpasterstwie opłacają zryczałtowany podatek dochodowy, mając oczywiście dobrowolną alternatywę opłacania podatku PIT na zasadach ogólnych ${ }^{20}$.

Natomiast duchowni zatrudnieni na podstawie stosunku pracy w instytucjach kościelnych paradoksalnie znaleźli się w sytuacji wprost odwrotnej do tej z czasów PRL. W kwestii dostępu do systemu ubezpieczeń nie są w żaden sposób dyskryminowani, jeśli chodzi o ubezpieczenie zdrowotne. Nieco odmiennie natomiast wygląda sytuacja w odniesieniu do ubezpieczeń społecznych. Składki na pozostałe ubezpieczenia opłacane są na zasadach ogólnych, wspólnych dla wszystkich zatrudnionych na takiej samej podstawie. Nie korzystają jednak oni w tym zakresie z dofinansowania składek ubezpieczeniowych z Funduszu Kościelnego (w wysokości 80\%) przysługującego ubezpieczonym z tytułu pozostawania w stanie duchownym, czyli na ogół pracującym w duszpasterstwie i nie zatrudnionym na podstawie umowy o pracę lub podobnej. Nie jest to jedyna różnica...

Trudno zatem wskazać słabe punkty warunków podatkowo-ubezpieczeniowo - formalnych, które realizują duchowni pracujący w duszpasterstwie i pełniący swoją misję na mocy wewnętrznych regulacji właściwego Kościo-

18 Ustawa z dnia 17 maja 1989 r. o ubezpieczeniu społecznym duchownych, Dz. U. z 1989 r. Nr 29 poz. 156 z późn. zm.

19 Ustawa z dnia 13 października 1998 r. o systemie ubezpieczeń społecznych, tekst jedn. Dz. U. z 2017 r., poz. 1778 z późn. zm.

20 Ustawa z dnia 20 listopada 1998 r. o zryczałtowanym podatku dochodowym od niektórych przychodów osiąganych przez osoby fizyczne, tekst jedn. Dz. U. z 2017 r., poz. 2157 z późn. zm. 
ła lub innego związku wyznaniowego, w przypadku Kościoła Katolickiego - na mocy prawa kanonicznego. Wypada natomiast przyjrzeć się sytuacji i możliwościom jej modyfikacji w przypadku duchownych zatrudnianych na podstawie umowy o pracę w instytucjach wyznaniowych (kościelnych). Poza dyskusją oczywiście pozostaje forma zatrudnienia duchownych u innych pracodawców (szkoły, uczelnie wyższe, szpitale, zakłady karne itp.), gdzie ich status duchownego zasadniczo nie ma znaczenia w określaniu warunków i form zatrudnienia (może być on w niektórych przypadkach wymagany do objęcia określonego stanowiska, np. kapelana, ale potem warunki są generalnie określane przez przepisy prawa państwowego).

Można odnieść wrażenie, iż po roku 1989 instytucje kościelne „odetchnęły” i z rozmachem skorzystały z braku jakichkolwiek właściwie ograniczeń w zawieraniu umów o pracę ze swoimi pracownikami - duchownymi, w szerokim znaczeniu tego słowa (wliczając też zakonników i siostry zakonne). Takie „odreagowanie” było w tamtych czasach zrozumiałe i wytłumaczalne. Obecnie, po niemal 30 latach, można już podjąć nad tym dyskusję mając za sobą nie tylko czas, ale również bagaż doświadczeń oraz perspektywę ewentualnych zmian. Podobnie jak w latach PRL, tak i obecnie władzom kościelnym wydaje się przyświecać myśl wyboru formy zatrudnienia najlepiej odpowiadającej rodzajowi misji i urzędu pełnionego przez duchownego oraz korzystnej dla samego zatrudnianego. Żeby mieć obraz bardziej kompletny trzeba się przyjrzeć zaletom i wadom obydwóch dostępnych rozwiązań z punktu widzenia zatrudnianego oraz pracodawcy.

\section{STOSUNEK PRACY}

Forma stosunku pracy, wynikającego głównie z umowy o pracę, jest niewątpliwie bardziej sformalizowana i precyzyjna, jeśli chodzi o warunki zatrudnienia, zakres obowiązków oraz wynagrodzenie i jego pochodne. Określa precyzyjnie pozycję pracownika (czas pracy, urlopy, świadczenia) i zabezpiecza go przed zaniedbaniami ze strony pracodawcy ${ }^{21}$. Może być korzystna w przypadku pracowników ,zewnętrznych” i pracy urzędniczo-biurowej (siostra zakonna w kurii, zakonnik w seminarium diecezjalnym

21 Por. Komentarz do art. 22 Kodeksu pracy, Goździewicz, Zieliński 2017, Lex nr 542519. 
itp.). Daje podstawę do dochodzenia ewentualnych roszczeń w przypadku nieporozumień i konfliktów. Skutkuje odprowadzaniem składek i zaliczek na podatek od całości wypłacanego wynagrodzenia, zwłaszcza gdy przekracza ono poziom minimalny. Powoduje również tworzenie oficjalnej i udokumentowanej historii zatrudnienia, wynagrodzenia, świadczeń itp., na potrzeby przyszłych pracodawców lub urzędu skarbowego, czy też Zakładu Ubezpieczeń Społecznych. Ogranicza jednak ochronę z ubezpieczenia wypadkowego (wypadku przy pracy) na czas pracy, drogę do i z niej.

Z punktu widzenia pracodawcy jest stosunkowo „kosztownym” sposobem zatrudniania $\mathrm{z}$ powodu różnicy $\mathrm{w}$ kwotach netto i brutto wynagrodzenia. Ograniczać to może kwoty, które zatrudniający skłonny jest przeznaczyć na wynagrodzenia w tej formie. Powoduje powstawanie kosztów pochodnych zależnych od liczby etatów zatrudnionych u tego samego pracodawcy. Ogranicza możliwości swobodniejszego kształtowania czasu i miejsca pracy poza określonymi w umowie.

Odrębnym zagadnieniem, powodującym trudności w sytuacji zwłaszcza kontroli przeprowadzanych przez ZUS lub organy skarbowe, jest swoista „dwoistość” sytuacji zatrudnianego duchownego. Duchowny taki oczywiście staje się pracownikiem zatrudniającego ze wszystkimi konsekwencjami wynikającymi z umowy o pracę. Jednocześnie jednak nie przestaje być duchownym ze wszystkimi konsekwencjami wynikającymi z wewnętrznego prawa danego Kościoła lub innego związku wyznaniowego. Stosunek pracy nie wyczerpuje zatem wszystkich łączących ich więzi. Po obu stronach pozostają zatem prawa i obowiązki nie ujęte w umowie o pracę. Duchowny, z racji swojej przynależności kościelnej (inkardynacji), nabywa prawa do „wystarczającego, godnego i dożywotniego utrzymania”22 ze strony odpowiedniej kościelnej osoby prawnej (diecezji, zakonu itp.). Wynagrodzenie ze stosunku pracy może, ale nie musi wyczerpywać całości świadczeń na rzecz duchownego ${ }^{23}$. Część tych świadczeń może być przekazywana w naturze - zwłaszcza wyżywienie i zamieszkanie. W tym zwłaszcza zakresie rodzą się nieporozumienia - takie bowiem świadczenia pracodawcy na rzecz pracownika są zaliczane (czy też raczej bywają podejmowane takie próby) do ,świadczeń w naturze i innych nieodpłat-

22 Zob. Walencik 2007, 187-209.

23 Zob. Liskowski 2016, 32-42. 
nych świadczeń" 24 , które to z kolei, po ustaleniu ich wartości, podwyższają kwotę przychodu pracownika, a w konsekwencji dochodu będącego podstawą opodatkowania podatkiem dochodowym od osób fizycznych oraz podstawą wymiaru składek na ubezpieczenia społeczne i zdrowotne. Podstawą nieporozumień jest określenie ,świadczenia pracodawcy na rzecz pracownika" nie uwzgledniające złożoności sytuacji duchownego. Organy kontrolujące domagają się częstokroć obliczania wartości posiłków, dokonywania pomiarów powierzchni mieszkań w celu obliczenia wysokości kwoty wynajmu itp. ${ }^{25}$ Ze strony kościelnej napotykają natomiast zarzuty nieposzanowania autonomii i niezależności państwa i Kościoła, wtrącania się w wewnętrzne sprawy kościelnych osób prawnych itp. Powoduje to konieczność składania nie zawsze uwzględnianych wyjaśnień lub uciekania się do rozwiązań wyłącznie formalnych, nie zmieniających charakteru wykonywania zadań przez duchownego. Do tych ostatnich można zaliczyć przykładowo zatrudnianie przez innego kościelnego pracodawcę niż ten, który świadczy na rzecz pracownika w naturze. Zatem duchowny mieszkający i pracujący w seminarium jest formalnie zatrudniony przez kurię, a pracujący i mieszkający w budynku kurii diecezjalnej - jest zatrudniony przez seminarium. Formalnie zabezpiecza to przed kłopotliwą sytuacją, choć z ekonomicznego punktu widzenia duchowny wciąż pozostaje ,,pracownikiem" swojej diecezji, a w sytuację zaangażowane tylko zostają jej dwie, odrębne, osoby prawne.

PEŁNIENIE POSŁUGI W RAMACH INSTYTUCJI KOŚCIELNEJ

Przez pełnienie posługi w ramach instytucji kościelnej (wyznaniowej) rozumiemy pełnienie zadań powierzonych duchownemu przez odpowiedniego przełożonego (zgodnie z prawem wewnętrznym kościoła lub innego związku wyznaniowego). Klasycznym przykładem takiej sytuacji są funkcje proboszczów, wikariuszy i ich odpowiedników ${ }^{26}$. Problemem jest, czy to jedyne możliwe sytuacje? ${ }^{27}$

24 Art. 11 ust. 1 u.p.d.f.

25 Zob. Nurzyńska-Wereszczyńska 2017, 429-444.

26 Świto 2010, 41-50.

27 Por. wyrok SN z 5 maja 2010 r., I PK 201/09, LEX nr 1036598. 
Kwestie podatkowe i ubezpieczeniowe są w takim wypadku traktowane ryczałtowo, a kwestie formalne ograniczone do minimum. Ryczałt podatkowy uzależniony jest od ilości mieszkańców jednostki oraz miejsca jej położenia - jest jednak przewidziana stawka dla duchownych nie będących proboszczami ani wikariuszami ${ }^{28}$. Dla ubezpieczeń społecznych i zdrowotnych podstawą wymiaru składki jest kwota minimalnego wynagrodzenia $^{29}$. Składki na ubezpieczenia społeczne korzystają z $80 \%$ dofinansowania z Funduszu Kościelnego. Ubezpieczeniem duchowny objęty jest praktycznie przez cały czas pełnienia urzędu - o jego kwalifikacji ewentualnie decyduje przełożony. Ma to znaczenie zwłaszcza w odniesieniu do ubezpieczenia wypadkowego i kwestii wypadków przy pracy. Formalnościami są: zgłoszenie do ubezpieczeń, decyzja naczelnika urzędu skarbowego i roczne deklaracje podatkowe. Finansowo i formalnie jest to rozwiązanie bardzo korzystne dla duchownego.

Minusem takiego rozwiązania jest ograniczenie przywilejów ubezpieczeniowych do podstawy wymiaru składki równej minimalnemu wynagrodzeniu - upraszczając, zakłada to w przyszłości minimalne świadczenia emerytalne. Ewentualne podniesienie podstawy (opłacanie składek od wyższej kwoty niż minimalna pensja) lub inna forma oszczędzania na przyszłe świadczenia pozostaje w decyzji ubezpieczonego i odbywa się na jego koszt, bez współudziału Funduszu Kościelnego.

Z punktu widzenia przełożonego sytuacja taka jest korzystniejsza z powodu braku obciążeń wypłacanych na rzecz podwładnego środków (zaliczki na podatek dochodowy, składki ubezpieczeniowe itp.). Nie powoduje również wzrostu liczby etatów pracowniczych, a więc nie powoduje konieczności odprowadzania innego rodzaju składek (PFRON, Fundusz Pracy itp.). Pozwala również na podstawie wewnętrznych regulacji w swobodniejszy sposób kształtować formy i zakres wykonywania zadań przez podwładnego, w odniesieniu do czasu, miejsca itp. Trudno bowiem wyobrazić sobie pracę np. ojca duchownego, wychowawcy w seminarium

28 Art. 45 ust. 4 Ustawy o zryczałtowanym podatku dochodowym od niektórych przychodów osiąganych przez osoby fizyczne, tekst jedn. Dz. U. z 2017 r., poz. 2157, (dalej: ustawa o ryczałcie).

29 Art. 18 ust. 4 p. 5 a Ustawy z dnia 13 października 1998 r. o systemie ubezpieczeń społecznych, tekst jedn. Dz. U. z 2017 r. poz. 1778. 
duchownym, dyrektora wydziału duszpasterskiego czy ekonoma w kurii pracujących w ścisłych ramach „biurowych”.

\section{PODSUMOWANIE}

Kościół w prezentowanym okresie zabiegał zawsze o to, aby charakter zatrudnienia duchownych $\mathrm{w}$ instytucjach kościelnych był zgodny $\mathrm{z}$ obowiązującym prawem państwowym i odpowiadał rodzajowi misji i urzędu kościelnego. W ramach możliwych rozwiązań starał się zastosować te, które uważał za najbardziej korzystne ekonomicznie i organizacyjnie. Był gotów na różnego rodzaju rozwiązania formalne, które nie zakłócały wypełniania posługi przez duchownego. Możliwości takich działań były czasami bardziej, a czasami mniej ograniczane przez politykę władz polityczno-państwowych oraz w konsekwencji przez przepisy prawa i praktykę organów wyznaniowych w czasach PRL. Podobnie przyjęte czasami nolens volens rozwiązania z upływem czasu i zmianami ustroju należy oceniać odmiennie.

Przy ocenie obecnie obowiązujących rozwiązań i możliwych w ich ramach konfiguracji nie uwzględniano w szacowaniu ewentualnych korzyści lub strat trzeciego elementu układu sił - skarbu państwa. W tym bowiem zakresie obowiązuje zasada domniemania racjonalności po stronie ustawodawcy. Jeśli pozostawił on do wyboru zainteresowanym stronom różne możliwe rozwiązania, to należy domniemywać, iż nie jest zainteresowany wyborem któregokolwiek z nich, pozostawiając inicjatywę i rzeczony wybór duchownym i ich pracodawcom.

\section{BIBLIOGRAFIA}

Garlicki, Leszek (red.). 2003. Konstytucja Rzeczypospolitej polskiej. Komentarz. Warszawa: Wydawnictwo Sejmowe.

Goździewicz, Grzegorz, Tadeusz Zieliński. 2017. „Komentarz do art. 22 Kodeksu pracy". Ludwik Florek (red.), Dorota Dzienisiuk, Katarzyna Gonera, Grzegorz Goździewicz, Monika Latos-Miłkowska, Łukasz Pisarczyk, Jacek Skoczyński, Joanna Unterschutz, Barbara Wagner, Piotr Wojciechowski, Tadeusz 
Zieliński. Kodeks Pracy. Komentarz. Warszawa: Wolters Kluwer Polska. Lex nr 542519.

Liskowski, Mariusz. 2016. „Pojęcie wynagrodzenia za pracę w Kodeksie pracy”. Pracownik i Pracodawca 2, nr 2: 32-42.

Nurzyńska-Wereszczyńska, Edyta. 2017. „Dobrowolne nieodpłatne świadczenia pracodawcy na rzecz pracownika w kontekście przychodu podatkowego ze stosunku pracy". Roczniki Administracji i Prawa 17 (tom specjalny): 429-444.

Raina, Peter. 1994. Kościót w PRL. Kościót katolicki a państwo w świetle dokumentów 1945-1989. T. 1: lata 1945-59. Poznań: Wydawnictwo „W drodze”.

Stanisz, Piotr. 2005. „Rola przepisów regulujących ubezpieczenie społeczne duchownych w realizacji polityki wyznaniowej państwa w latach 1945-1989". W: Prawo i polityka wyznaniowa w Polsce Ludowej: materiaty II Ogólnopolskiego Sympozjum Prawa Wyznaniowego (Kazimierz Dolny, 26-28 października 2004), red. Artur Mezglewski, Piotr Stanisz, Marta Ordon, 271-295. Lublin: Wydawnictwo KUL.

Świto, Lucjan. 2010. „Charakter prawny posługi duszpasterskiej proboszczów i wikariuszy w parafiach rzymskokatolickich w świetle prawa polskiego". Seminare 27: 41-50.

Walencik, Dariusz. 2007. „Prawo duchownych do utrzymania w unormowaniach Kodeksu Prawa Kanonicznego z 1983 roku”. Roczniki Nauk Prawnych 17, nr 1: 187-209.

\title{
FORMS OF EMPLOYMENT OF THE CLERGY IN CHURCH INSTITUTIONS AFTER WORLD WAR II
}

\author{
Summary
}

The aim of the present article is to present the existing possibilities for the employment of the clergy by church institutions, that is, by the so-called church employers. The first part of the study depicts the situation in this regard from the end of World War II till the turn of 1989/1990. During that period, the position of public authorities clashed with that of church authorities, and the former treated the issue of the employment of the clergy in an instrumental manner, in a similar way to their social insurance and taxation. The discussion presented in this part is based on legal acts and archival documents which illustrate the way in which the law was understood and applied at the time. After 1989, the socio-economic context has undergone major changes. There are no formal obstacles for church entities to employ the clergy in employment relationships. The choice of the type 
of employment rests with clergymen and their employers, and the second part of the study aims to present the existing alternatives and discuss the benefits and risks/ challenges associated with the current situation.

Key words: employment of the clergy; forms of employment; remuneration; work; clergyman; church employer; religious organization

Ttumaczenie: Daria Bębeniec 